\title{
“Damızlık Kızın Öyküsü”: Arendt'in doğarlık düşüncesi karşısında yeniden üretim mülkü olarak beden
}

\section{Duygu ÖZAKIN ${ }^{1}$}

\begin{abstract}
APA: Özakin, D. (2019). “Damızlık Kızın Öyküsü”: Arendt’in doğarlık düşüncesi karşısında yeniden üretim mülkü olarak beden. RumeliDE Dil ve Edebiyat Araştırmaları Dergisi, (17), 495-514. DOI: $10.29000 /$ rumelide.657929
\end{abstract}

$\ddot{\mathbf{O} z}$

Bu çalışma, Kanadalı yazar Margaret Atwood’un “Damızlık Kızın Öyküsü” (The Handmaid’s Tale) adlı romanını yeniden üretim olarak tanımlanan üreme politikaları çerçevesinde, feminist edebiyat eleştirisi yöntemiyle ele alır. Bir feminist distopya örneği olan roman, sağlıklı doğurgan kadınların, ekolojik nedenlerle çocuk sahibi olamayan üst düzey ailelere hizmet etmek üzere görevlendirildikleri ve salt yeniden üretim mülkü haline getirildikleri izole edilmiş bir düzeni anlatır. Feminizmin ikinci dalgasında biyolojik farklılık kavramına eğilen yaklaşım, kadının doğasına vurgu yaparak “özcü” bir anlayışla hak arayışlarını sürdürmüştür; ancak kadınların kamusal alandan dışlanarak özel alana hapsedilmesi ile sonuçlanan bazı söylemlerle örtüşmesi bakımından eleştirilmiştir. 20. yüzyılın en etkili kadın siyaset felsefecilerinden biri olarak tanınan Hannah Arendt'in "doğarlık" (natality) anlayışı da, düşünürün kendisini hiçbir zaman feminist hareket içinde konumlandırmamış olmasına karşın, aynı itiraz noktalarından hareketle tenkit edilmiştir. Bu çalışma, Arendt’in tekillik ve tutsaklığa karşı çoğulluk ve özgürlüğü simgelemesi bakımından "mucize” olarak nitelediği doğum fenomeninin distopik tahayyülünü, "Damızlık Kızın Öyküsü” örneğinde tartışmayı amaçlar. Biyopolitika literatürüne feminist yaklaşımların imkânını araştıran çalışmada, her devirde devletin tasarruf yetkisi altında bulunan doğumun, sadece pozitif eylem potansiyeline sahip olmadı̆̆ı; kavramın özgürlükçü ya da baskıcı rejimler eliyle iki farklı anlam dünyası tarafından kuşatılabileceği sonucuna erişilmiştir.

Anahtar kelimeler: Damızlı Kızın Öyküsü, feminist distopya, doğarlık, biyopolitika, yeniden üretim.

\section{"The Handmaid's Tale": The body as a reproduction property in contrast to Arendt's notion of natality}

\begin{abstract}
This study recontextualizes Canadian writer Margaret Atwood's novel "The Handmaid's Tale" following the method of feminist literary criticism within the framework of reproductive policies defined as reproduction. The novel, as an example of feminist dystopia, describes an isolated regime in which healthy women are assigned to serve elite childless families due to the ecological conditions. These women are charged with breeding in the fictional Gilead Republic's caste system and turned into reproductive properties. The second wave of feminism is criticized for its "essentialist" understanding that emphasizes the very nature of women as this approach coincides with some discourses on the exclusion of women from the public sphere and the confinement of them into the private sphere. Hannah Arendt, known as one of the most influential political philosophers of the
\end{abstract}


2oth century, has also been criticized for the same motives, although the philosopher herself never took a position on behalf of feminist movement. This study aims to discuss the dystopic imagination of the phenomenon of natality, which Arendt calls "miracle" as the metaphor of plurality and freedom against singularity and captivity, in the case of "The Handmaid's Tale". The study, investigating the possibility of feminist approaches to biopolitical literature, concluded that birth, which is under the authority of the state, does not only have the potential for positive action. The concept can be surrounded by two different semantic fields under libertarian or repressive regimes.

Keywords: The Handmaid's Tale, feminist dystopia, natality, biopolitics, reproduction.

\section{Giriş}

Yurttaşların biyolojik yaşam süreçlerinin politikanın sınırlarına dâhil edilmesi ve özel alandan çıkarılıp kamusal alanın meselesine dönüştürülmesi olarak ifade edilebilecek biyopolitika kavramı, ilk kez İsveçli siyaset bilimci Rudolf Kjellén tarafından kullanılmıştır (Lemke, 2014: 26). Kjellén bu yeni kavramı 1905 yllında yayımlanan "Büyük Güçler" ve 1916 yılında yayımlanan "Bir Yaşam Biçimi Olarak Devlet" adlı çalışmalarında ortaya koymuştur (Gunneflo, 2015: 24). Kjellén’in biyopolitika anlayışı, devleti bir organizma olarak yorumlayan yaklaşımların (organizmacı devlet kuramının) uzantısı niteliğindedir ve devlet içindeki bağımlı sistemleri ve güç savaşlarını, bedenin işleyişine benzetmektedir. Ancak biyopolitikanın bir araştırma disiplini olarak daha derinlikli bir niteliğe bürünmesi Fransız düşünür Michel Foucault'nun çalışmalarıyla mümkün olmuştur. Foucault'ya göre, 17. yüzyıldan başlayarak iktidar, nüfusu cezalandırmak amacıyla öldürmekten ziyade, onu yaşatmaya eğilimli görünmektedir. Zira canlı insanların ıslah edilmesi ve yeteneklerinden egemen lehine fayda sağlanması, daha akla yakın ve çağın gereklerine uygun bulunmuştur (Foucault, 2007: 103).

Biyopolitika literatürünü feminist bir perspektifle taramak, ilgili literatür, egemenin mutlak gücünün açığa çıkarılması kadar eril egemen söylemin de ifşası anlamına geldiğinden, toplumsal cinsiyet çalışmaları çerçevesinde beden odaklı bir tarih okuması yapmak için oldukça çeşitli ve bir o kadar tartışmalı bir arşive ulaşmayı sağlar. Biyopolitika yapıcıların ve kuramcılarının metinleriyle iki farklı kanattan oluşan bu birikimin ilk ayağında tarihsel figürler, devlet, din ve bilim "adamları", kadını kaba bir toplumsal-işlevsel kategorizasyon içine, bedensel niteliklerini ve sözde "aksaklıklarını" önceleyerek hapseder. Siyaset ve bilimin dili, özellikle de tıp bilimi, "eksik erkek olarak kadın" varsayımından hareket ederek kurduğu kadın düşmanı (misojinist) kurallar sistemini rasyonalize etme ve olağanlaştırma eğilimindedir. Biyopolitikanın kuramsallaştırılma ve tartışma aşamasına ait metinlerse, feminist düşünürler tarafından, kadını bir çözümleme kategorisine indirgedikleri halde, kadın hareketi ile işbirliği içinde çözüm arayışına uzak kalmaları gibi nedenlerle eleştirilir.

"Felsefenin Kadına Bakışı" başlıklı çalışmasında Berktay, felsefecilerin tarihsel ve toplumsal koşullardan bağımsız olarak hakikati aradıkları iddiasına karşın, felsefe etkinliğinde sınıfsal, ırksal, cinsel ve dinsel aidiyetlerin dünyayı ve kendilerini algılama biçimlerine etki ettiğini belirtir. Ezici bir çoğunlukla erkeklerden oluşan felsefe dünyasının etkinliklerinin sonuçları "erkeğe ait bir uğraş olarakfelsefe"den her ne anlaşllyorsa, onun izdüşümü olarak ortaya konulmuştur. "Kadınlarn ve dişil olanın bu gelenekten dışlanması, kasıtl bir komplo değil, var olan toplumsal koşulların doğal bir sonucudur"

Söz konusu kısıtlılığa ilişkin Hannah Arendt'in ilk okurlarından ve eleştirmenlerinden biri olan Amerikalı kadın şair Adrianne Rich, Arendt düşüncesinde örneklenen, bir kadın filozofun toplumsal cinsiyet duyarlı olmayan bakış açısını "Erkek ideolojilerinden beslenen kadın zihninin trajedisi" sözleriyle sert biçimde eleştirmiştir (Disch: 1995: 286). 
(Berktay, 2010: 23). Berktay, bu koşullar değiştikçe, felsefenin de değişeceğini ve feminist felsefenin gelişiminin de bunun göstergelerinden biri olduğunu hatırlatır.

Müspet bilimlerin ve akıl yürütme faaliyetinin erkeklerin tekelinden aşamalı olarak çıkarak, eril eylem alanlarından insancıl eylem alanlarına dönüşmesi, biyopolitika çalışmalarına da yeni bakış açıları kazandırmaktadır. Bu çalışma, özünde pozitif ayrımcı olması beklenen biyopolitik çözümlemenin yeni bir imkânı olarak feminist biyopolitik perspektifi, Margaret Atwood'un "Damızlık Kızın Öyküsü" (The Handmaid's Tale) adlı distopyası üzerinden inceler. Yeniden üretim paydaşı olarak kadın bedeninin mülk haline getirilmesini ve bu sürecin gerek biyopolitika kuramcıları tarafından, gerekse farklılık ya da öz fikrine vurgu yapan feminist yorumlamalar tarafından ikincil mesele haline getirilme, olağanlaştırılma ve yok sayılma nedenlerini tartışır. Feminizmin ikinci dalgası içinde yeşeren bu görüşler, birinci dalganın sosyal, siyasal ve ekonomik platformlarda kadın erkek eşitliğini kabul ettirme mücadelesinin aksine, kadının özünde taşıdığı farklılıkları, kadının doğasından kaynaklanan içsel gücü biçiminde ortaya koyma eğiliminde olmuştur.

Çalışma, kadınlığın değil insanlığın "durumunu” soruşturması sebebiyle kendini kadın hareketi içinde konumlandırmaktan imtina eden ve araştırmacılar tarafından feminist bir filozof olmadığı vurgulanan Arendt'in, olumlu bir biyopolitik kategori olarak ifade ettiği "doğarlık” kavrayışında, ikinci dalganın özcü söylemleriyle örtüşen hatlara ışık tutar. Çalışma, totaliter bir düzende doğumun, bir olgu olarak içerdiği yeniden başlangıç ve umut gibi değerlere karşın nasıl çarpitılarak yıkıcı bir amaçla uygulamaya konabileceğini tartışan görüşlere yer verir. Kuşkusuz Arendt, ilerleyen bölümlerde söz edileceği gibi, doğarlık kavrayışını en geniş anlamıyla insanın dünyaya gelmesi, vücut bulması, yaratılması; kısaca "başlangıcın başlangıcını" temsil etmesi gibi felsefi bağlamlarda ele almış, kadın bedenini doğrudan ilgilendiren "doğurma" eylemini bilinçli olarak teğet geçmiştir. Ancak doğarlığa yönelik eleştirel okumalarda, Arendt’in kavramını üzerine inşa ettiği olumlu koşulları verili ve değişmez kabul ettiği ve olumsuz sonuçlar yaratabilecek değişkenlere yer vermediği hususunda ulaşllan kanaat birliği dikkat çekicidir. Zira doğarlık felsefesinde arzu edilen çeşitlilik, totaliter rejimin hüküm sürdüğü koşullarda, düzenin devamlılığını sağlayacak tek tip vatandaşın yaratılması neticesinde bertaraf edilmektedir. Toplama kamplarında yaşanan kadına yönelik cinsel savaş suçları kapsamında ise doğarlık, bir kültürün asimile edilmesi ya da toptan silinmesine yönelik zorbalığın aracı haline gelmektedir. Bu çalışmada incelenen feminist distopya ise, doğarlı̆̆ın negatif ihtimaller arasında saydığımız her iki koşulla etkileşime girmesinin sonuçlarına ayna tutan uyarı mahiyetinde bir kurgu olarak değerlendirilmiştir.

\section{Feminist distopya olarak “Damızlık Kızın Öyküsü”}

Kanadalı yazar Margaret Atwood'un 1985 yılında yayımlanan romanı "Damızlık Kızın Öyküsü", doğurgan sağlıklı kadınların, çocuk sahibi olamayan üst düzey ailelere hizmet etmek üzere görevlendirildikleri, Gilead Cumhuriyeti’ne özgü kast sisteminde yer alarak salt yeniden üretim mülkü haline getirildikleri izole edilmiş bir düzeni anlatan, distopik bir kurgudur. Okur, bir damızlık kız olan Offred'in dilinden anlatılan hikâyede, geriye dönüşler sayesinde, Gilead öncesi "normal” yaşamın, bir darbeyle nasıl değiştiğine, rejimin darbe sonrasında kadınların özgürlüklerini ve bedenlerini zapturapt altına alarak, gündelik hayatı nasıl adım adım kâbusa çevirdiğine tanıklık eder.

“Damızlık Kızın Öyküsü” eleştirel ütopya, distopya, feminist distopya gibi türlere dâhil edilmiş olsa da, çalışmada başvuracağımız araştırmacılar bu eserin özgürlüklerin yitirildiği baskıcı bir yapılanmada kadın duyarlığını önceleyen bir bakış açısının ürünü olduğu konusunda fikir birliği içindedir. Bu açıdan eser, feminist distopya olarak adlandırılan ve kıyamet tasavvurunu kadın bakış açısından sunan türün 
genel özelliklerini taşımaktadır. Ütopya kavramıyla ifade edilen pozitif bir hayali yerin, arzu edilen bir "yok ülkenin" aksine distopya, genellikle totaliter rejimin kuşatması altında felakete sürüklenmiş, baskı ve terör nedeniyle tek tipleşmiş toplumların negatif bir görünümünü sunan hayali "kötü bir yerdir". Edebi tür olarak ise distopyanın en etkili ve dünyaca tanınmış örnekleri arasında Yevgeni Zamyatin'in "Biz”, George Orwell’in "1984" ve "Hayvan Çiftliği”, Aldous Huxley'nin "Cesur Yeni Dünya”, Ray Bradbury'nin "Fahrenheit 451" adlı eserleri sayılabilir. Anılan eserlerde, toplum üzerindeki topyekûn baskının birer panoraması sunulurken; kadınların "normal" hayatlarında tecrübe ettikleri baskıyı ve edilgenliği ikiye katlayan sistemdeki konumlarına özel bir hassasiyet göstermeye gerek duyulmadığı, kadın yazarların kaleminden çıkan distopya örnekleri ile kıyaslandıklarında kolayca fark edilmektedir. Atwood'a göre distopyaların çoğu, erkekler tarafından ve eril bir bakış açısıyla yazılmışlardır. Bu distopyalarda kadınlar ya cinsiyetsiz otomatlar ya da rejimin cinsiyet kurallarına meydan okuyan isyancılar olarak boy gösterirler. Oysa Atwood, "kadın bakış açısından" aktarılan bir distopya kurgulamaya çalışmıştır (Atwood, 2004: 516). Bu yorum farkının temelinde ise "kadın edebiyatı" adı verilen ve "kadınlar için kadınlar tarafından" kaleme alınan edebi metinlerin kategorik ayrılıklarından ziyade Argunşah'ın (2016: 14) önerdiği gibi "edebiyatta kadın duyarlı̆̆ı" vurgusuna başvurmak daha doğru görünmektedir. Bu duyarlık, Margaret Atwood, Katharine Burdekin, Suzy McKee Charnas, Suzette Haden Elgin, Zoe Fairbairns gibi kadın yazarları feminist distopya olarak adlandırılan türde eserler vermeye yönlendirmiştir.

“Damızlık Kızın Öyküsü” ayrıca, bir "biyopolitik distopya” örneği olarak da ele alınabilir. "Biyopolitik Distopya: Yorgos Lanthimos Sinemasından ‘İnsan' Manzaraları” adlı çalışmasında ütopya ve distopya kavramlarının mantıksal açıdan sağlamasını yapan Kartal'a göre "ütopya iktidarn yok yeriyse kavramın değillemesi olarak distopya da pekâlâ iktidarm her yerde oluşunu ifade edebilir" (Kartal, 2018: 101). Distopyanın biyopolitik karakterini açımlayan araştırmacıya göre distopyanın yapısı, iktidarın her yeri ve her şeyi kapsayarak gözetim altına aldığı bir dünyayı anlatması bakımından biyopolitikanın kuşatmacı niteliğiyle uyuşmaktadır. "İktidarın yok yeri olarak ütopyanın karşısında iktidarn her yerde oluşu olarak distopya, zorunlulukla biyopolitiktir” (Kartal, 2018: 102). Çalışmasında Atwood'un distopyasına da değinen Kartal, distopik evrenini baskıcı üreme politikaları üzerine kuran bu romanı, bilhassa Foucault'nun atıfta bulunduğu Viktoryen ahlak anlayışına yer vermesi bakımından "günümüz biyopolitik distopyasını" bir örneği olarak yorumlar (Kartal, 2018: 112).

"Distopik Devletin Biyopolitikası” adlı çalışmasında Ekiz, distopyayı modern yönetim pratiklerinin disipline edici özellikleri ile ilişkilendirerek, kavramın "bedene, üretici güçlere, üretim ilişkilerine ve nüfusa egemen olma" (Ekiz, 2018: 17) pratikleriyle belirlenen biyopolitik karakterine 1şı tutar. "Nüfusun, hayatın (bios) tüm sorunlart, kolektif niteliği gereği iktidarn müdahale alanına çekilmektedir" (Ekiz, 2018: 13). Bu bakımdan biyopolitik çerçevede hareket etmeye başlayan "yönetim kendi mekanizmaların geliştirdikçe, distopik kurguların bir mecazına dönüşmektedir. Kullanılan dilde, çalışma düzeninde, yaşamın her alanında kâbus sıradanlaşır, olağanlaşır ve kabul edilir" (Ekiz, 2018: 13). Ekiz, distopik evrenle reel yaşam arasındaki karşlıklı yansımayı sadece hayattan kurgusal olana doğru yola çıkmak suretiyle değil; aynı zamanda kâbusun gerçekleşmesi bakımından, distopyanın içinde yaşadığımız düzendeki izdüşümleri aracılığıyla da ele almaktadır. Ekiz de Kartal gibi üretim ve yeniden üretim süreçlerinin distopik kurgulardaki rolüne dikkat çeker: "Üretici güçlerin gelişmesine bağh olarak nüfusa gömülü emek stokunun ve emeğin yeniden üretiminin kontrolü/denetimi ayn zamanda sözünü ettiğimiz bu biyopolitik bir zeminde gerçekleşmektedir” (Ekiz, 2018: 15). 
Atwood'un yeniden üretim olgusunun üremeye ilişkin kanadı üzerinde kurulan denetim ve baskıyı merkeze aldığı distopik romanında damızlık kızlar, yerleştirildikleri evde bir süreliğine ikamet eder, bu evde çocuk doğurma görevleri sona erdiğinde, yeni bir ailenin yanına verilirler. Özgün birer isme sahip değildirler, hizmetinde çalıştıkları komutana atfen "Fredinki (Offred), Gleninki (Ofglen), Warreninki (Ofwarren)" gibi isimlerle çağrılırlar. Distopya kahramanlarına isimleri yerine numara, kod adı, damga gibi yeni kimlikler verilmesi türün klasik özellikleri arasında yer alır. Böylece distopyanın içine düşen kahraman, özgün kimliğinden ve eski yaşantısından koparılarak bir insandan bir "şeye" dönüştürülür.

\begin{abstract}
"İsmim Fredinki değil, başka bir ismim var, artık kimse kullanmıyor bunu, çünkü yasak. Kendi kendime bunun önemli olmadığını, ismin telefon numaraları gibi olduğunu, sadece başkalarının işine yaradığını söylüyorum, ancak bu doğru değil, aslında önemli. İsmimin varlığını gizli bir şey gibi saklıyorum, geri dönerek kazıp ortaya çıkaracağım bir hazine, günün birinde. Bu ismin gömüldüğünü düşünüyorum” (Atwood: 1992: 99).
\end{abstract}

Romanda Offred olarak anılan anlatıcı June, darbeyle beraber işini kaybetmiştir. Darbeden sonra kadınların çalışması yasaklanır, bu nedenle kendini ve ailesini tehlikeye atmak istemeyen genç kadın, günlerini ev işleriyle oyalanarak geçirmeye çalışır. Olağanüstü halin sona ermesini beklerken, yeni rejim tarafından eşinden ve çocuğundan uzaklaştırılır, egemen zoruyla bir damızlık kız olarak görevlendirilir. Her grubun görev tanımının keskin sınırlarla belirlendiği bu sistemde damızlık kızlar kırmızı renkli, rahibe giysilerine benzeyen tek tip bir elbise giymek zorundadırlar. Başlarına, çevrelerinde olup bitenleri görmelerini engelleyen ve başkalarının da onları gözlemlemesine olanak vermeyen beyaz kanatlı başlıklar geçirirler. "Her şey, yüzümün yanlarındaki kanatlar hariç, kırmızı: bizi belirleyen kanın renginde. Elbise ayak bileklerine kadar uzanıyor, bol, göğüsleri çevreleyen geniş bir bağla toplanıyor, kollar da bol. Beyaz kanatlar da emir gereği; görmemizi engellemek için, görülmemizi de tabii” (Atwood, 1992: 14).

Damızlık kızların gündelik hayatları çizelgelere tabi tutulmuştur. "Elimizi kaldırırsak tuvalete gidebiliyoruz, gerçi günde birkaç kez olduğuna dair bir sinırlama var, çünkü bir karta işliyorlar bunu” (Atwood, 1992: 84). Rejimin belirlediği saatlerde muhafızlar eşliğinde evin ve mutfağın çeşitli ihtiyaçlarını karşılamak üzere sınırı bir alanda dışarı çıkmalarına izin verilir. Temel ihtiyaçlar, karneyle karşılanır, mallar değiş-tokuş edilir, para ise Gilead Cumhuriyeti'nde tedavülden kalkmıştır. Anlatıcı Offred, umutsuzluğun neden olduğu itaatkârlıkla tanışır, düzene uyum sağlayarak daha az acı çekmeye gayret eder. "Fazla düşünmemeye çaba gösteriyorum. Başka şeyler gibi, şimdi düşünce de karneye bağlanmal” (Atwood, 1992: 13). Yeni sistemde “özgür” en tehlikeli sifata dönüşmüş ve özgürlük kavramı etrafında şekillenen tüm fikirler yasadıșı ilan edilmiştir. "Hatırlayamıyorum. Bu tür şarkılar artık herkesin arasında söylenmiyor, özellikle özgür gibi sözcükler içerenler. Aşırı tehlikeli diye kabul ediliyorlar. Yasadışı mezheplere ait bu şarkılar” (Atwood, 1992: 65).

Damızlık kızların hizmet ettiği komutanın ailesiyle beraber yaşadıkları evler "görev yeri" olarak tanımlanır. Damızlık kızlar kendi aralarında ancak onaylanmış, sınırlı, mekanik cümle kalıplarıyla konuşabilirler. Rejim kendi gözetim sistemini Tanrı'nın gözleri metaforu ile özdeşleştirir. Vatandaşlara her saniye denetlendiklerini hissettirmek amacıyla göz, gözetme ve gözetlenme arasındaki belirsiz ve endişe verici bağlar sıklıkla hatırlatılır. "Tanrı Gözetsin, diyor. Uygun veda sözü" (Atwood, 1992: 55).

Devamlı gözetim altında tutulan damızlık kızların arkadaş edinmeleri, kendi özgün cümleleriyle özgürce sohbet etmeleri ve özellikle kitap okumaları ve yazmaları yasaklanmıştır. Gilead iktidarı, kadınların söz söyleme yetilerinin ellerinden alınmasının, onları kontrol altında tutmanın teminatı olduğunun farkındadır. Bu nedenle, damızlık olarak hizmet vermeyi reddeden çeşitli mesleklerden kadınlar, bu püriten düzende hala varlığına izin verilen genel evlerde çalışmakla cezalandırılır. Bu mekânların 
müdavimleri arasında, sistemin en yetkili kişileri sayılan komutanların da bulunması, sistemin ahlaki ikiyüzlülüğünü yansıtması bakımından dikkat çekicidir.

“Damızlık Kızın Öyküsü”, yeniden-üretim’in çifte anlamının üreme kategorisine odaklanırken, üremeye ilişkin çeşitli görüşlerin, baskıcı yapılanmalar altında nasıl suistimal edilebileceğini feminist distopya türünün olanakları sayesinde okura sunmaktadır. Dolayısıyla, eseri incelemeye başlamadan önce yeniden-üretimin ana hatlarıyla tarif edilmesi ve annelik olgusuna ilişkin farklı bakış açılarından, olgunun tarihsel dönüşümü çerçevesinde söz edilmesi gerekir.

\section{Üretim ve yeniden-üretim süreçlerinde kadının konumu üzerine görüşler}

“Ailenin, Özel Mülkiyetin ve Devletin Kökeni” adlı çalışmasında Engels, materyalist anlayışa göre, tarihte egemen etkenin, maddi yaşamın üretimi ve yeniden üretimi olduğunu, ancak bu sürecin ikili bir karaktere sahip olduğunu ortaya koyar. Engels, bu süreci "bir yandan, yaşam araçlarının, beslenmeye, giyinmeye, barnmaya yarayan nesnelerin ve bunlarn gerektirdiği aletlerin üretimi; öbür yandan bizzat insanlarn üretimi, türün üremesi” (Engels, 2003: 8) olarak açıklar. Engels’in tasnif ettiği biçimiyle türün üremesi olarak "yeniden üretim", kadın hareketinin üreme politikaları bağlamında benimseyerek başvurduğu temel bir kavram haline gelmiştir.

Türün yeniden üretiminin yani üremenin teminatı olarak kadın bedeninin yeniden anlamlandırılması, tarih boyunca sadece kutsal kaynaklardan ve geleneksel inanışlardan beslenmemiştir. Üreme, 18 . yüzyıldan itibaren sanayi toplumuna dönüşmekte olan dünyanın pragmatik düşünce yapısında önemli ve merkezi bir rol oynamaya başlamıştır. Orta Çă̆'da ekonomik yetersizlik ve salgın hastalıklar sonucu yaşanan toplu ölümlerle ilintili olarak çocuk ölümlerine gösterilen kayıtsızlı̆̆ın aksine modern dönemde iktidar, anneliğe atfedilen "kutsallığı" seküler bir düzlemde, dinî referansın yerine modern ve müspet vaatler koyarak yeniden canlandırma gayretinde olmuştur. Bu gayreti değişik perspektiflerden ele alarak içselleştiren ya da eleştiren feminist anlayışların anneliğe yaklaşımları arasında da belirli farklılıklar göze çarpmaktadır.

Coontz'a göre Engels ve Marx'ın metodolojilerinde önemli bir husus, aile hayatını ve yeniden üretimi, gerek tarihsel güçlerin bir ürünü olarak, gerekse kendi başına tarihsel bir güç olarak değerlendiren bakış açılarıdır (Coontz, 2012: 231). Ferguson'a göre, insanların üretimi, şeylerin üretildiği yerlerden farklı bir mekânda ya da alanda gerçekleşir, bu bakımdan ebeveynlik, kadın ile erkek arasında eşitsiz ve sömürücü bir düzende üretilir. Zira kadınlar, insan üremesi ve dolayısıyla hizmetlerin üretimi üzerinde çok daha az kontrol sahibidirler. Burada üreme, yani insanın biyolojik olarak yeniden üretimi, aynı zamanda, işgücünün de yeniden üretimi anlamına gelmektedir (Ferguson, 2012: 239-242).

Anneliği, devletin korumakla yükümlü olduğu bir toplumsal işlev olarak kabul ettirmeye çalışan feministler, haklar mücadelesinde anneliğin kadınlara sunabileceği ayrıcalıkları önceleyerek "anneliğin yüceliği” argümanına başvurur. Collin ve Laborie bu çabayı, “anneci feminizm” olarak adlandırırlar (Collin \& Laborie, 2009: 39). "68 kuşağı sonrası feministlerin sloganları arasında "İstediğimiz çocuklara, şayet istersek sahip olacağız” ve "Bedenimiz bizimdir” söylemleri öne çıkmıştır, böylelikle kadınların 1970'lerin ortalarından itibaren, çocuk sahibi olup olmama konusunda daha özgür bir zeminde hareket edebilmelerinin önü açılmıştır. Radikal feministler ise "anneci” olarak nitelendirilen ve ikinci dalganın bir bölümünü teşkil eden feministlerin aksine, anneliği erkeklerin kadınlar üzerindeki egemenliğinin merkezi bir ögesi, bir denetleme, boyunduruk altına alma, hatta kölelik biçimi olarak görme eğilimindedirler (Collin \& Laborie, 2009: 42). Gelişen tıbbi olanaklarla beraber üreme teknolojileri, soy 
bağlarını, biyolojik ve sembolik ebeveynlik ayrımına ilişkin keskin sınırları karmaşıklaştırmıştır. Taşıyıcı anneye başvurulan bir senaryoda, doğumu yapan kadın biyolojik anne olduğu halde yasal anne saylmamaktadır (Collin \& Laborie, 2009: 43). Doğurganlık, bütün toplumlarda güçlü bir denetime tabidir ve bu denetim üreme zorunluluğunun (yani yeniden üreticilik işinin) kadınlara yüklenmesini ifade edebileceği gibi, doğumların yasaklanması ya da dayatılması anlamlarına da gelebilir (Lhomond, 2009: 65).

Yaşamın biyopolitik idaresinin sürdürülmesinde üremenin, yeniden üretim sürecinin etkin rolü, doğrudan kadın bedenini ilgilendirmektedir. Üreme politikalarının, biyopolitikanın merkezi meselelerinden biri olarak ele alınması, feminist araştırmacıların duyarlı̆̆ı sayesinde mümkün olmuştur. Ancak doğum fenomenine ilişkin görüşler sadece feminist araştırmacı ve yazarların eleştirel bakış açıları ile püriten dünya görüşünün dayatmacı zihin yapısı arasında sıkışıp kalmamıştır. Doğum fenomeni, kendi özgül doğası içinde ele alınan bir değer olarak, filozofların da soruşturduğu ve pozitif bir anlam dünyasıyla kuşattığı kavramlar arasındadır. Bu bağlamda, 20. yüzyılın kadın filozofları arasında ilk akla gelen isimlerden biri olan Hannah Arendt’in "doğarlık" (natality) kavrayışına eğileceğiz. Arendt’in doğarlık kavrayışına yöneltilen feminist eleştirilere yer verdikten sonra ilgili kavramı "Damızlık Kızın Öyküsü" çerçevesinde ele alacağız. Nihayetinde Arendt'in doğum olgusuna pozitif yaklaşımıyla örtüşen ve günümüz toplumunun, karamsar bakış açısından uzaklaşması gerektiğini; ancak bu yolla insan hak ve özgürlüklerinin temin edilebileceğini savlayan görüşlerle çalışmayı sonuca erdireceğiz.

\section{Hannah Arendt’te “doğarlı”" (natality)}

Hannah Arendt (1906-1975), siyaset felsefesi alanında 20. yüzyllın en etkili kadın düşünürlerinden biri olarak tanınır ve totalitarizmin kaynaklarına olduğu kadar; topyekûn egemenliğe karşı direnme olanaklarına da ışık tutan bir filozof ve siyaset bilimci olarak adından söz ettirir. "İnsanlık Durumu" adlı eserinde doğum ve ölüm, doğarlık ve ölümlülük kavramlarına eğilen Arendt’e göre doğarlık "doğuyor olmak, doğmuş olmak" olgusudur. Arendt düşüncesinde bir "mucize" olarak değerlendirilen bu olgu, yeni insanların doğmasıyla, yeni "başlatıcıların" ortaya çıkması anlamına gelir. Mucize, insan türünün "doğmak suretiyle muktedir olduğu eylem" potansiyelinde bulunmaktadır (Arendt, 1994: 338). Mucize, söz konusu eylem potansiyelinde gizil güç olarak bulunan direnme ve düzeni dönüştürme imkânına işaret etmektedir.

Arendt'e göre eylem, insanın doğarlık durumuyla yakından ilgilidir; "doğumda içkin olarak bulunan yeni başlangıcı kendini bu dünyada duyurabilmesi, sadece, yeni doğmuş biri yeni bir şeye başlama yani eyleme yeteneğine sahip olduğu için mümkündür" (Arendt, 1994: 19). Arendt, doğum fenomenini dünyaya duyulan inanç ile umudun bir emaresi sayar ve bunun "belki de en görkemli ve özlü ifadesini" İncil'de yer alan birkaç sözde bulduğunu vurgular: "Müjdeler olsun./Bu çocuk bize geldi" (Arendt, 1994: 338). Arendt, doktora tezini Ortaçağ düşünürü St. Augustine’in (M.S. 354-430) felsefesi üzerine hazırlamıştır. ${ }^{3}$ Augustine'in "başlangıçta, kimse yokken insan yaratıldı" sözlerini de doğarlık kavrayışı ekseninde değerlendirmiştir. Arendt Augustine'in bu sözünde, bir "şey"in değil, bizzat kendisi başlayan olan "biri"nin yaptığı başlangıcın söz konusu edildiğini vurgular. Arendt'e göre özgürlük ilkesi, daha önce kendiliğinden değil de, bizatihi yeniden başlangıcı temsil eden insanın yaratılmasıyla dünyaya giren bir ilkedir (Arendt, 1994: 243).

“Der Liebesbegriff bei Augustin” başlı̆̆ıyla 1929 yılında; "Love and Saint Augustine” başlığıyla 1996 yılında basılmıştır. 
"Hannah Arendt’in Doğarlık Kavrayışı ve Siyaset Felsefesi İçin Yeni Bir Hareket Alanı” adlı çalışmasında Kartal, Arendt'in Hıristiyanlıktan "ilahi olmayan bir tarzda" beslendiğinin altını çizer ve onun Augustine'e atfını, totaliter pratiklerden olduğu kadar totalitarizmin varlığını borçlu olduğu felsefi anlam dünyasından da uzaklaşma girişimi olarak okur. "Bu kaçış için hareket noktası, doğumun beraberinde getirdiği başlangıçtan başka bir şey değildir” (Kartal, 2018: 205). Arendt'in yaşamla, başlangıçla ve çoğullukla ilişkilendirilen doğarlık kavrayışının, biyopolitik kuram açısından olumlu pencereler açtığını ifade eden Kartal'a göre Arendt “ölümün karşısına doğarlı̆̆, yalnızlık ve ilişkisizliğin karşısına kamusallğ̆ ve çoğulluğu, sonluluğun sükûnetine karşı yaşamın sözünü çıkarmıştır" (Kartal, 2018: 201). Doğarlık yoluyla çoğulluğun kaynağına erişen Arendt, bir önceki bölümde ele aldığımız yeniden üretim ilişkilerini göz önünde tutarak, emeğin yeniden üretim bağlamında ele aldığımız ikili anlamına vurgu yapar ve kavramını "hayat verme" eylemiyle ilişkilendirir:

"Emeğin yakın zamanda yeniden keşfedilen üretkenliği gerçek anlamını sadece, Marx'ın, üretkenliği doğurganlıkla eşitleyen çalışmalarında belli eder. Öyle ki insan cinsinin 'üretici güçleri’nin, 'yararlı şeyler' ile dolu bir topluma doğru ünlü ilerleyişi, gerçekte aboriginal (özden/kaynaktan gelen) buyruktan başka hiçbir yasaya boyun eğmez ve başka hiçbir zorunluluğa da tabi değildir; 'doğur ve çoğal!'; sanki doğa seslenmektedir” (Arendt, 1994: 148-149).

Özgürlük kavramının bireysel hürriyetten daha fazlasını ifade ettiğini savlayan Arendt'e göre, özgürlük, ancak toplumla etkileşim halinde anlamlı kılınabilir. Doğarlık felsefesiyle ilişkilendirilen özgürlük, yeniden başlama özgürlüğü anlamına gelir ve düşünür, insanlığın sürdürülebilir olmasını yüce bir eylem olarak kabul eder. Arendt düşüncesinde "doğurganlık, yaşamın kuvvetidir" (Arendt, 1994: 151) ve yaşamla içsel bir bağıntısı bulunan emeğin doğası hayat vermekle ilintilidir. "Yeni bir şeyin başlamakta oluşu, başlangıcın doğasından ileri gelir o nedenle, yeni, daima bir mucize kılığında ortaya çıkar. İnsanın eyleyebilir olması, (...) sonsuz olasılıklardan birini gerçekleştirebilir olması demektir” (Arendt, 1994: 243).

Doğarlık ya da başlangıç felsefesi olarak anılan bu kavrayışta, özgürlüğün bir teminatı olarak başlangıç ilkesinin, dolayısıyla yeniden üretimin yüceltilmesi, kadın hareketinin dikkatinden kaçmamıştır. Totschnig'e göre, Arendt düşüncesinde statükodan kurtulma ve yeni şeyler başlatma kapasitesine işaret eden bir metafor olarak doğarlık, bir biyolojik süreç olan doğumun yerini almıştır (Totschnig, 2017: 338) ancak bu durum, aşağıda değinileceği gibi, kadını siyasal alanda görünmez kılmıştır. Arendt’in insanın eylemliliği ve doğumu arasında özdeşlik kurarak, doğumdan bir felsefi kategori olarak söz etmesinin, çoklukla kadını özel alana hapseden yeni yorumlamalara kaynaklık ettiği ve kadını sadece çocuk dünyaya getirmeye yarayan canlı bir aracıya indirgeyen görüşlerle bir arada anıldı̆̆ düşünüldüğü için, doğarlık kavrayışı güçlü bir tepkinin odağına yerleştirilmiştir. Çalışmada önce doğarlık kavrayışına yönelik eleştirilere; daha sonra "Damızlık Kızın Öyküsü”nde doğum fenomeninin distopik görünümlerine yer verilecektir.

\section{Doğarlık kavramına yönelik feminist eleştiriler}

1950 yllında İstanbul'da dünyaya gelen felsefeci Seyla Benhabib’in yeni perspektifler açan ve "Arendt ile Arendt'e karşı düşünmek" olarak tanımladığı eleştirel okuma anlayışı, Arendt'e yönelik feminist eleştirilerin temel eğilimini belirlemiştir. Benhabib, çağdaş feminist teori için Arendt düşüncesinin -özgürlük/zorunluluk, kamusal alan/özel alan ve kadın/erkek arasında kurulan bazı karakteristik ayrımlara dayanması nedeniyle- "şaşırtıcı, zorlayıcı ve bazen de rahatsız edici” (Benhabib, 1993: 97) olduğunun altını çizer. Bu düşünce silsilesi Benhabib’in deyimiyle "toplumsal cinsiyet duyarl olmayan" (gender-blind) bir karaktere sahiptir (Benhabib, 1993: 101). 
"Kadınlık Durumu ile İlişkisinde Hannah Arendt” adlı çalışmasında Coşkun, doğasında yeni bir şeyleri temsil etmek ve onları harekete geçirmek olan başlangıcın önemine vurgu yapan Arendt'in düşünce evreninde, kadın hareketini rahatsız eden kategorileri anlamaya çalışır ve bunların yanlış yorumlanmaya yatkın yönlerini tespit ederek düşünürün görüşlerini yeniden okur.

\begin{abstract}
“Arendt'in düşünme nesnesi edindiği şeye Arendt'le aynı yerden bakılmadığında, kadınların neredeyse bir suçmuş gibi taşıdıkları bedenlerinden ötürü- kamusal yaşamın dışında kalmasını ve kenara itilmesini onayladığı, zorunlulukların hâkim olduğu özel alanı değersiz bulduğu, özel-kamusal ayrımında ısrar ederek aslında eril bir politika anlayışını savunduğu sonucuna varılabilir elbette. Ancak ya öyle değilse?” (Coşkun, 2013: 8).
\end{abstract}

Coşkun, Arendt'e yönelik feminist okumaları soruşturduğu makalesinde Arendt'in insanlık durumuna karşılık niçin kadınlık durumuna özel bir önem atfetmediğini açıklar. Arendt’in kadınlık durumuna ilişkin tespitlerden kaçınmasının nedeni, düşünürün hâlihazırda bir tür "erkeklik durumuna" vurgu yapmaktan da kaçınmış olmasıdır. Arendt, daha ziyade insanı genel olarak ilgilendiren eylemleri cinsiyet gözetmeksizin konu edinmiştir (Coşkun, 2013: 10). Ancak kadının, toplumun kadim inanışlarından sistematik düşünme faaliyetlerine, sosyal bilimlerden tıp bilimine dek çeşitli alanlarda erkeğin ötekisi, erkeğin eksik hali, erkek olmayan şey ve nihayet varlığı özel alanla sınırlanması gereken cins olarak tanımlanması, erkekle özdeşleştirilen "insan" karşısında kadının problemlerini ayrı bir paragraf açarak ele almayı zorunlu kılmaktadır.

“Damızlık Kızın Öyküsü”nde Gilead rejiminin söylevlerindeki başlıca atıflar St. Paulus (Aziz Pavlus, M.S. 10-67) gibi Orta Çağ düşünürlerinin vecizlerine yapılmaktadır. Arendt ise doğarlık kavrayışında mucize adını verdiği ilkeye St. Augustine’in "başlangıçta, kimse yokken insan yaratıldı" sözlerinden hareketle açıklık getirmektedir. Arendt’in, Augustine’in sözlerini teolojik düzlemden çıkarıp seküler alana hizmet edecek biçimde yeniden konumlandırdığı (Willard 2013; Kartal 2018) hatırlatılmaktadır. Ancak Atwood'un roman kahramanının dilinden ifade ettiği gibi "bağlam her şeydir" (Atwood, 1992: 166). Kadınların Orta Çağ çileciliğine ve kadın bedenini tarla olarak görmeye eğilimli toplumsal anlayışa, bu ötekileştirici düşünme biçimlerinin araçlarını ödünç alarak karşı durmaya çalışmasının ve kadınlara özgürce yaşama şansı tanınmayan dönemlerden miras kalma söylevlere dayanarak çağdaş toplumda kendilerine yer bulabilmelerinin imkânı yoktur. Arendtçi doğarlık kavramı başlangıcı temsil eden insanın ana rahminden değil, hiçlikten çıkıp dünyaya geldiğini kabul etmektedir (Cavarero, 1995: 6), dolayısıyla düşünür, bedensiz bir doğum anlayışını benimsemiştir (Willard, 2013: 227). Ancak bu zımnî (üstü kapalı, ima edilen), bedensiz, soyut anne bir nesneye indirgenmiş; siyasetin koşulu olan çeşitliliğin üretiminde bir araç haline getirilmiştir. Willard'a göre doğan (doğarlık yetisi bulunan) vatandaş, kamusal yaşamın aydınlık ışı̆̆ında "ortaya çıkar", buna karşılık onu dünyaya getiren anne bilinmeyendir, karanlığa gömülmüştür (Willard, 2013: 242).

Coşkun, Arendt’in “İnsanlık Durumu”nda eylem ile insanın çoğulluk durumu arasındaki bağı açıklamak üzere başvurduğu ve kadının konumuna işaret ettiği bazı görüşleri sıralamaktadır. Bunlar arasında, “Damızlık Kızın Öyküsü”ndeki distopik sistemde önemli bir düşünsel figür olan Aziz Pavlus da yer almaktadır:

“Eski Ahit'in Yaratılış bölümünde geçen “Tanrı onları erkek ve kadın olarak yarattı” ifadesine gönderme yapması, karı-koca ilişkisiyle ilgili bir tartışmada İsa'nın da Tekvin'de geçen bu cümleye başvurduğuna işaret etmesi, Pavlus'ta ise kadının “erkekten” yaratıldığı ve dolayısıyla 'erkek için' olduğu vurgusunun öne çıtı̆̆ını hatırlatması” (Coşkun, 2013: 12). 
$\mathrm{Bu}$ sıralamayı, Augustine’in başlangıç ve mucize olarak doğuma işaret ettiği atıflarla sürdürmek mümkündür. Arendt, Augustine'den kadın duyarlığını öncelemeksizin ilham almıştır. Bu ifadelerde çoğulluğun koşulunu ararken, doğumun aracı olarak kadının konumunu tartışma gereği duymadığı gibi, egemene karşı durmaya çalışırken başka egemenlik biçimlerinin ötekileyici diline yaslanmıştır. Hiçbir zaman feminist hareket içinde söz almamış olan Arendt’in doğarlığın imkânları konusunda akıl yürütme biçiminin, dayandığı kaynakların ve eriştiği sonuçların; feminizmin ikinci dalgasının en fazla eleştiriye uğrayan söylemleri ile örtüşmesi bu bakımdan dikkat çekicidir. İkinci dalga feminizmin özcü çerçevesinde anneliğin cinsiyetlendirilmiş avantajlar bakımından önemli bir yer teşkil etmesini eleştiren Atwood ise, distopyasında çoğalma eylemini kutsal anlam dünyası ile kuşatan Orta Çağ felsefecilerini Gilead rejiminin düşünsel kaynakları ve önderleri olarak öne çıkarmıştır. Böylelikle biyolojik özün farklılığına yaslanarak ayrıcalık elde etmeye çalışan kadın hareketleri ile Orta Çă̆ söylemlerini birleştiren söylevlerin doğrusallığını ve risklerini distopik evrende çarpıcı örneklerle sunmuştur. Arendt ise, doğarlığı eylemlilikle ve tirana karşı koymakla ilişkilendirip, onu muktedirin dayattığı tekilliğin karşısına çıkarılacak çoğulluğun bir koşulu olarak ele alıyorsa da, kutsal kaynaklardan seçtiği doğuma ve çoğalmaya yönelik anımsatmalar, doğarlığın özellikle kadını ya da doğurma eylemini ilgilendirmeyen bir felsefi kavram olarak okunamayacağının ipuçlarını sunmaktadır.

Arendt için doğarlığın kaynağı olan doğum; gebe kalma, hamilelik ve doğurma süreçlerini kapsayan biyolojik bir fenomen değildir (Cavarero, 2014: 17). Doğarlığın asıl somut malzemesi maddi bedendir, Arendt bu gerçeği önemser ama nihayetinde düşüncesinin temeline bedeni yerleştirmekten de kaçınır (Trimble, 2011: 265). Arendt’in Orta Çağ kaynaklarından esinlenerek türettiği doğarlığı "soyut, bedensiz ve cinsiyetsiz" (Söderback, 2017: 1) bir perspektiften ele alması; insanı erkekle eşitleyen asimetriyi göz ardı etmesiyle, entelektüel çevrenin cinslerden birini hiyerarşinin alt basamağında konumlandırdığı gerçeğine gözlerini kapamasıyla ve bu durumun ön ayak olabileceği sorunlara kulaklarını tıkamasıyla sonuçlanmıştır. Bununla birlikte, “doğur ve çoğal!'; sanki doğa seslenmektedir” ve "doğurganllk, yaşamın kuvvetidir” (Arendt, 1994: 149-151) sözleriyle, kavramsallaştırması içinde görünmez kıldığı kadın bedeninin yeniden üretimdeki konumuna işaret etmektedir.

Benhabib’e göre, Arendt’in Yahudi kimliğine dair öz farkındalığı ve 20. yüzyılda bir Yahudi olmanın politik ve kaçınılmaz bir gerçek haline geldiği yönündeki inancı, onun kadın problemi konusundaki mutlak sessizliğiyle tam bir karşıtlık içindedir. Yahudi halkının kaderi onun politik düşüncesinin merkezinde yer alırken, kadın kimliği ve modern dünyada kadın olmanın sosyopolitik ve kültürel boyutları konusunda aynı şeyi söylemek mümkün değildir (Benhabib, 1995: 5). Felsefe profesörü Patricia Altenbernd Johnson, Arendt’in bir Yahudi olarak kendi kimliğine sahip çıkmasına rağmen, kadın kimliğine asla bu kadar sahip çlkmadığını; 1960'lı ve 1970'li yıllarda ortaya çıan feminist hareketin "gereksiz ve ideolojik" olduğuna inandığını belirtir (Johnson'dan akt. Coşkun, 2013: 2). Arendt, hareketin temsil ettiği sorunların büyük bir bölümünü esasen politik değil; sosyal problemler olarak kabul etmektedir (Markus, 1987: 84). Buna karşllık kadın hareketi de, Arendt’in metinlerinde yansımasını bulan ve dini kaynaklara dayandırılan bu düşünme biçiminin tehlikelerini, düşünürü anlayarak ve fikirlerini gerekçelendirerek bertaraf etmeyi olanaksız bulmaktadır. "Damızlık Kızın Öyküsü "adlı romanın muhalif alt metni, kadın bedenini hedef alan baskıcı politikalara yönelik 1970'lerde filizlenen feminist şerhe dayanmaktadır ve Arendt 1970'lerin itirazlarını "gereksiz ve ideolojik" çlkışlar olarak, daha önemli meseleleri ötelediği gerekçesiyle düşünce çemberinin içine dâhil etmemektedir. Arendt’in periferiye ittiği hak taleplerinin Atwood'un dikkat çekmek istediği biçimde, kadının bireysel sorunu olmaktan çıkıp toplumsal travmanın merkezinde konumlanması, doğarlık ve başlangıç yerine; doğarlık ve sonlanma arasında kurulabilecek riskli bağlantıların sorgulanmasına neden olmuştur. Bu sorgulamalar, Benhabib’in “Arendt ile Arendt’e karşı düşünme” olarak tanımladığı 
çerçevede gerçekleştirilmiştir. Benhabib’e göre yapmamız gereken, düşünürün kuramlarını yeniden yorumlamak kadar onları revize etmektir; bu durumda kendimize Arendtçi sorular sorup, bunlara Arendtçi olmayan yanıtlar bulmamız gerekmektedir (Benhabib, 2003: 198).

Benhabib’in görüşlerinden yola çlkan ve doğuma atfedilen mutlak "mucizenin" arzu edilmeyen koşullarda nasıl kitlesel felaketlere dönüşebildiğine dair kapsamlı bir çalışma olan "Natality and Destruction: Arendtian Reflections on War Rape" (Doğarlık ve Yıkım: Savaş Tecavüzleri Üzerine Arendtçi Düşünceler), Danimarkalı felsefe profesörü Robin May Schott tarafından kaleme alınmıştır. $\mathrm{Bu}$ çalışmasında Schott, kadına yönelik savaş suçlarına Arendt-karşıtı bir perspektiften yaklaşmaktadır. Koşulsuz olarak yüceltilen doğum fenomeni ile kadına yönelik savaş suçları ve soykırım arasında trajik bir ilişki bulunduğunu düşünen Schott, savaş suçları arasında yer alan cinsel şiddetin, felsefe sahasında yeniden ele alınması gerekliliğini vurgular, cinsel şiddet probleminde de, insan bedeni ve politik beden (body politic) arasındaki ilişkiye işaret etmenin bir gereklilik olduğunu not eder. Çalışmasında Arendtçi doğarlık kavrayışından yola çıkan Schott; buna karşılık, kendi deyişıyle bazı "Arendtçi olmayan" sonuçlara ulaşır.

Schott, 1937 yılında yaşanan vakalarda sayıları seksen bine ulaştığı tahmin edilen Çinli kadının Japon askerleri tarafından ve II. Dünya Savaşı boyunca iki milyon kadının Sovyet askerleri tarafından uygulanan cinsel şiddete maruz kaldığını ifade eder. Auschwitz'den kurtulan kadınlar arasında da bir türlü “iyileşemeyenler" savaşta erkek şiddetine maruz kalanlar olmuştur. 1990'lar boyunca ise Bosna, Yugoslavya ve Ruanda'da yaşanan savaşlarda kadınların kaderi değişmemiştir. Schott’a göre, istatistiklere geçirilmesi engellendiği için görünmez kılınan bu suçlar, kurbanların ruhlarında silinmesi olanaksız hasarlar bırakırlar ancak zamanla bedende bıraktıkları izler silindiği için, siyasal bakımdan hasıraltı edilmeleri kolaylaşır, dolayısıyla politik olarak görünmez kılınırlar. Schott, bu suçların artık sadece kişinin haysiyetine yönelik değil, tüm insanlık onuruna karşı işlenen suçlar kapsamında değerlendirildiğini ifade eder (Schott, 2010: 50).

Schott, beden ve politika arasındaki ilişkiyi, doğum kavramı ve onun cinsel şiddet suçlarındaki dönüşümü etrafinda ele almaktadır. Arendt’in doğum fenomenine ilişkin görüşlerine yer veren araştırmacı, düşünürün doğarlık kavramını, insan yaşamındaki yeni başlangıçlara vurgu yaparak sunduğunu anımsatır. Arendt'in politik yaşam anlayışında hayati bir role sahip olan doğarlık kavramının, yeni başlangıçları temsilen doğumun metaforik anlamı ile örtüştüğünü, ölüm ve sonlanma karşısında politik bir belirleyici olarak işlev gördüğünü tespit eder. Ancak bu tespitle yetinmeyen Schott, Arendt'e yönelik bir takım eleştiriler ortaya koyar. Antik filozofları ve şehir-devlet (polis) düzenini takip eden Arendt'e göre doğal, biyolojik beden, mutlak, sorgulanamaz "yaşam durumu"nu ifade eder, dolayısıyla Arendt, toplumsal cinsiyet kategorisine kayıtsız kalmıştır; aynı şekilde anneliğe ve kadınlığa da. Onun doğarlık felsefesi, cinsiyetsiz bir çerçevede inşa edilmiş metaforik anlamlar taşımaktadır. Ayrıca doğarlık, politik yaşamın "mutlak" koşullarından biri olarak ortaya konmaktadır. Schott, insanlık durumunun temel bir parçası olarak doğarlığın, yıkımın sahası haline getirildiğinde ne gibi sonuçlara sebep olabileceğini tartışır. Totaliter rejimin baskısı altında ya da ölüm kamplarında hakiki politik yaşamın kaybı, doğarlığın kaybı anlamına gelmektedir (Schott, 2010: 52). Bu koşullarda Arendt’in "mucize" olarak adlandırdığı şey tersine çevrilir. Yazar, bu tespitini savaşta tecavüze uğrayan Bosnalı kadınların ifadeleriyle örneklendirir. Doğarlık, bir topluluğu ortadan kaldırmak ya da soykırıma uğratmak amacıyla, topluluğun kadınlarını kasten hamile bırakmak anlamına da gelebilir (Schott, 2010: 63). Dolayısıyla, bir grup için yeniliğe ve mucizeye atılan adım, diğer topluluk için yıkım ve ölüm anlamlarına gelebilir. 
Zorla gebe bırakmada "biricik ya da eşsiz" olan tek şey, doğumun kendisinin, bir ölüm silahına dönüşmesidir. Bu bağlamda doğumun temel anlamı radikal bir dönüşüme uğratılmıştır (Schott, 2010: 63). Savaş suçları, insanlık durumunun temel özelliğini yıkmak suretiyle, kadınlara ve politik topluluklara ölüm getirir. Yazar, burada da yeni başlangıçların bulunduğunu, ancak bunların cellatlar için olumlu ve mucizevi, mazlumlar için ise yıkıcı olduğunu ifade eder. Doğarlıktan kaynaklanan başlangıç, siyasal koşullara göre yenilenmeyi içeren umudun da, başkasının yaşamını gölgeleyen umutsuzluğun da kaynağı olabilmektedir. Schott, güç ve şiddetin biyolojik terimler olarak yorumlandığı, şiddetin, yaşamın sözümona "yaratıcılığı" için aklandığı olumsuz örneklerle doğarlığı tartışır ve insanın "cinsiyetlendirilmiş" doğasına yapılan vurgunun risklerine işaret eder. Zira totaliter yapılanmalarda, savaş dönemlerinde ve kamplarda insanın üretken boyutu, yaşam değil, ölüm aracına dönüştürülmüsstür (Schott, 2010: 62).

Arendt doğarlık kavramını insan varoluşunun olumlu yanlarını vurgulamak için kullanmıştır ve bunu yaparken medeniyetin kırılganlığını formülünün dışında tutmayı yeğlemiştir. Schott, Arendt düşüncesinde doğarlığın tek taraflı ele alınmasına karşı kavrama "kırılganlık" çerçevesinden yaklaşmayı önermektedir. Zira birinin /bir şeyin kapasitesi ya da zayıflıkları, koşulların değişkenliği neticesinde o şeye karşı kullanılabilir, ona yöneltilebilir. Doğarlığa sadece olumlu ve "mucizevi” anlamlar yüklemek, insan yaşamına sızan belirsizlikleri ve insan ilişkilerindeki asimetrik güven ve güç ilişkilerini göz ardı etmenin bir sonucudur. Yazar, kırılganlığı, doğarlığın bir boyutu olarak vurgular, zira yeni başlangıçların yıkıcı ve yapıcı olmak üzere iki farklı yüzü vardır. İnsanlık durumunun unsurlarından biri de "kırılganlık" kavramıdır, dolayısıyla insanın doğumu politik bir karaktere büründüğünde, bir ölüm formuna ve öldürücü bir silaha çevrilebilir. Tecavüz, zorla gebelik ve zorunlu annelik, doğumu bir ölüm silahına dönüştürür (Schott, 2011: 14) ve biyolojik anneleri ve yeni doğanları kamusal alandan dışlanma tehlikesiyle baş başa bırakır (Schott, 2011: 5). Görüldüğü üzere doğarlık, sağladığı eylem potansiyelinin içeriğine göre hem pozitif hem de negatif anlamlar taşımaktadır. Negatif anlamlar arasında ise, doğarlığın kaçınılmaz aracısı olan kadının yeniden üretim mülküne dönüştürülmesi yer almaktadır.

\section{Kadının yeniden üretim mülküne dönüștürülmesi}

“Damızlık Kızın Öyküsü”nde kadınların köleleştirildiği olası geleceğe ilişkin uyarı mahiyetinde bir kurgu ortaya koyan Atwood, dişil bedene lütfedilmiş bir takım biyolojik özelliklerin kadınların ayrıcalıklı konumuna vurgu yapmak amacıyla öne çıkarıldığı ve bu yolla kadının ötekiliğinin yeniden üretildiği söylemleri sorgulamaktadır. Yazar, bu sorgulama sürecinde kadını doğanın bir parçası olarak verimli topraklarla ilişkilendiren görüşleri mercek altına almaktadır. "Tanrı meyveyi kutsasın, diyor bana, aramızdaki onaylanmış selam sözü bu. Tanrı yolunu açsın, diye cevap veriyorum, onaylanmış karşıllk (Atwood, 1992: 26). "Bildik öykü, bildik öyküler. (...) Semereli olun ve çoğalın ve yeryüzünü doldurun" (Atwood, 1992: 104).

Roman kahramanı Offred, bir bebek dünyaya getiremeyen bedenlerin eksik, bu verimsiz bedenlerin sürdürdüğü yaşamınsa faydasız sayıldığı bir düzende, çocuksuz bir kadının eksikliğini gündelik ihtiyaçlara ilişkin çeşitli benzetmeler yoluyla tarif etmektedir: "Onun için salt kullanılacak bir beden değilim artık. Yüksüz bir tekne, içinde şarap olmayan bir kadeh -kabaca ifade etmek gerekirseçöreksiz bir tava değilim onun gözünde artık. Onun için salt boş bir şey değilim” (Atwood, 1992: 188). Gilead rejimi altında düzenli olarak tekrarlanan dua törenlerinde çoğalmayı kutsayan yakarışlar dile getirilir. Gilead sakinlerinin bir kısmı inanarak, bir kısmı ise cezalandırılmaktan korktukları için göstermelik, abartılı tepkilerle hamile kalabilmek amacıyla yalvarırlar: "Oh Tanrm, artndır beni. Verimli kıl. Nefsimi körelt ki üreyebileyim. Tatminkâr kıl beni... Kimi bunlarla kendinden geçerdi. 
Aşağılanmanın esrimesi. Kimi inleyip ağlardı. Kendini maskara etmenin anlamı yok, Janine, derdi Lydia Teyze" (Atwood, 1992: 223).

Offred, üreme amaçlı olarak Gilead'a getirilen kadınların, püriten ahlaki değerlerle uyum içinde, sadece yumurtalıkları çocuk sahibi olmaya elverişli taşıyıcılar olarak görevlendirildiklerini şu sözlerle anlatır: "Üreme amaçlar için varız biz: odalık, geyşa ya da fahişe değiliz. Tam tersine: bizi bu kategoriden çıkarmak için mümkün olan her şey yapılmış. (...) Biz iki bacakh rahimleriz, hepsi bu: kutsal tekneler, gezgin kadehler" (Atwood, 1992: 156). Ancak bu kadınların eğlence ya da tutku nesneleri haline getirilmemeleri, onların bedensel bütünlüklerinin kendi rızaları dâhilinde korunmasını sağlamaya yetmemiştir. Bu kadınların bedenleri birer araca indirgenmiş, duyguları köreltilmiştir ve Gilead'da gerçekleştirilen sistematik tecavüzlerin üstü çoğalmaya ilişkin kutsal söylemlerle kapatılmaya çalışılsa da, sistem her birini köleye dönüştürmüştür. Damızlık kızlar, komutanların eşlerinin gözetiminde düzenlenen bir çeşit üreme ritüeli eşliğinde hamile kalmaya zorlanırlar.

Gilead’ın damızlık kızları, içine itildikleri cehennemin kurallarını zamanla kanıksamaya başlarlar. Zira bu cehennemin kendi içerisinde katman katman derinleşen başka çukurları da vardır ve en akıllıca yol, daha az yakıcı tarafta kalmaktır. Çocuk doğurmaya uygun olmayan kadınlar, yaşlı kadınlar ya da muhalif kadınlar ölüm kolonilerine gönderilir. Rejime karşı geldikleri için ölümle cezalandırılanlara ait cansız bedenlerin istiflendiği kamplarda temizlik işleriyle görevlendirilirler ve salgın hastalıklar dolayısıyla kendileri de ölürler.

\begin{abstract}
"Atıklar ve radyasyon sızıntıları yüzünden oralarda burnun düşmeden ve derin lastik eldiven gibi soyulmadan önce en fazla üç yılın olduğunu hesaplıyorlar. Yedirip içirme, insana koruyucu giysi ya da başka bir şey verme zahmetine katlanmıyorlar, bunları yapmamak daha ucuz. Hem nasılsa, bunlar kurtulmak istedikleri insanlar çoğunlukla” (Atwood, 1992: 284).
\end{abstract}

Gilead'da doğurgan olmayanları ölmeye bırakan politikalar yürürlüktedir. Verimli ve geleceğin teminatı olan bedenler yaşatmayı merkezine alan biyopolitikanın; verimsiz ve işe yaramaz sayılan bedenlerse ölüm siyasetinin (thanatopolitikanın) hedefine yerleştirilmiştir. Gilead iktidarı, üç "şansını" da kullanmış (Atwood, 1992: 284) ancak yine de devlete bebek verememiş damızlık kızların yanı sıra yaşlı rahibeleri de kolonilere gönderir; genç ve doğurgan rahibeleri ise inançlarından döndürmeye çabalar. "Bunu başardıklarında ise hepimiz toplanıp bu törenden geçmelerini, evlenmeme yeminlerinden vazgeçip toplumun yararı için onu feda etmelerini izleriz” (Atwood, 1992: 252).

Bu nedenle "uygun yumurtalıklarım var. Bir şansım daha var" (Atwood, 1992: 165) düşüncesinde teselli bulan damızlık kızlar, hayatta kalabilmek için zorunlu doğumu kabul ederler ve kendilerinden önce hamile kalabilenlerin yerinde olmak isterler: "Bizim için o büyülü bir varlık, kıskançlık ve arzu nesnesi, ona imreniyoruz. Doruktaki bayrak o, bize hâlâ ne yapılabileceğini gösteren: biz de kurtarılabiliriz" (Atwood, 1992: 35). Gilead'da hamile kalmayı başaran kadınlar, devletin özel koruması altında tutulan değerli kamu malları olarak kabul edilirler. Dolayısıyla "bugünlerde, gebe kalma şansına erişebilmiş olan aklı başında hiçbir kadın bir doğumu engellemeye çalışmaz” (Atwood, 1992: 43). Çocuksuz kalmaları durumunda ölüme terk edilecek olan bu kadınlar, hamile kalmalarıyla beraber biyopolitikanın değerli nesneleri haline geldikleri için koruma altına alınırlar. "Kapının dışında onu bekleyen bir Muhafiz olmalı. Artık bir hayat taşıyıcısı olduğuna göre, ölüme daha yakın ve özel korumaya ihtiyacı var" (Atwood, 1992: 35). Gilead'da doğum, bir işe indirgenmiştir ve doğurgan kadınlar görevlerini bir an önce yerine getirip ölümden kurtulmaktan başka bir şeyi dilemez ve sorgulayamaz hale gelmişlerdir. "Tüplerim bağlanmamış olsaydı, ben de onlardan olabilirdim, on yaş daha genç olsaydım, sözgelimi. O kadar kötü değil. Hem ağır iş de denmez buna” (Atwood, 1992: 16-17). 
Offred'in kaldığı evin sahibesi Serena Joy, bir zamanlar ünlü bir şarkıcıyken git gide muhafazakâr bir imaja bürünüp kadınları özel alana hapseden görüşlere önderlik etmiştir. Bu kadın, damızlık kızların sürdürmek zorunda bırakıldığı yaşamın mimarlarından biridir. Serena Joy, vaazlarında hamile kalamayan kadınların "yenilgiye uğramış ve cinselliklerini kaybetmiş" (Atwood, 1992: 57) kadınlar sıfatıyla merhamete muhtaç olduklarını anlatır. Şarkı söylemeyi bırakıp söylev vermeye başladığında, söylevleri "evin kutsallı̆̆ı, kadınlarm nasıl evde oturmaları gerektiği hakkındaydı. Serena Joy kendisi böyle yapmıyordu, bunun yerine söylev veriyordu, ancak kendi başarısızhğım herkesin iyiliği için yaptı̆̆ bir fedakârlık olarak sunuyordu" (Atwood, 1992: 56).

Damızlık kızların kaçmasını engellemek için, toplama kamplarında yapıldığı gibi bedenlerine çeşitli simgeler işlenmektedir. "Şimdi ayak bileğimdeki küçük dövmeyi görmekten kaçınamıyorum. Dört rakam ve bir göz, karşıt anlamda bir pasaport. Asla başka bir yere doğru ortadan kaybolamayacağımı garantileme amacı taşıyor" (Atwood, 1992: 76). Damızlık kızların Gilead sınırları dışına çıkması, sadece otoriteye itaatsizlik anlamına gelmez. Hala üreyebilen sağlıklı kadınlar, devletin kendini garantiye alarak baki kalmasının en önemli teminatıdır. "Önemli, az bulunur bir şeyim. Ulusal bir kaynağım” (Atwood, 1992: 77).

Damızlık kızlar, hamile kalamadıkları her ayı korkuyla karşılamaktadırlar. Yaşamaları sisteme bir çocuk verebilmelerine bağlı olduğundan, hayatta kalıp kalmayacaklarını bedenlerindeki emareleri sürekli takip ederek öngörmeye çalışırlar. Bu kadınların tüm yaşamı, darbe öncesi sürdürdükleri hayattan eser kalmayan yeni düzenleri içinde, çoktan yabancılaşmış oldukları bedenlerinin onlara vereceği olumlu işaretlere pamuk ipliğiyle bağlanmıştır:

\begin{abstract}
"Basılacak yerleri sadece benim bildiğim bir bataklığa batar gibi bedenimin içine batıyorum. Tehlikeli topraklar, kendi bölgem. Geleceğin dedikodularını duymak için kulağımı dayadığım toprak oluyorum. (...) Her ay kanın gelmesini bekliyorum, korkuyla, çünkü gelmesi başarısızlık anlamını taşıyor. Diğerlerinin bana aitmiş gibi benimsediğim beklentilerini gerçekleştirmekte bir kez daha başarısız oldum" (Atwood, 1992: 86).
\end{abstract}

Damızlık kızlar özel muhafızlar eşliğinde düzenli olarak zorunlu jinekolojik muayeneden geçirilirler. Muayene esnasında tavandan aşağı sarkan bir çarşaf, damızlık kızların bedenini ikiye böler. Böylece hastanın yüzünü görmesi engellenen doktor, bir kadınla değil de sadece bir "gövdeyle" ilgilenmiş olur. $\mathrm{Bu}$ yolla püriten ahlaka uygun bir sağlık kontrolü gerçekleştirilir. Ancak istisnai durumlarda doktorlar kuralları çiğneyerek hastalarına birkaç söz söylerler. "-Bu ihtiyar heriflerin çoğu artık bu işi beceremiyorlar, diyor. Ya da kısırlar. -Neredeyse soluksuz kalıyorum: Yasak bir sözcük söyledi. Kısır. Artık kısır erkek diye bir şey yok, resmi olarak. Doğurgan ve kısır kadınlar var, kanun böyle”(Atwood, 1992: 72).

Gilead rejimi altında bedenleri birer nesneye indirgenen sadece kadınlar değildir ve üst düzey yönetici sıfatıyla özgüvenlerini yitirmemeye çalışsalar da, erkekler de ancak biyolojik yeterlikleri dolayısıyla saygınlıklarını muhafaza edebilirler. Kısır erkekler, damızlık kızların sağlığından mesul olan jinekologların aşağılayıcı sohbetlerine konu olurlar. Ancak Gilead'da erkeklerin kısır olabileceğini söylemek bir yana bunu düşünmek bile yasaktır. Sadece kadınlar, verimli ve verimsiz topraklar olarak ikiye ayrlabilirler. Yine de resmi kurallar, Gilead erkeklerinin de kendi bedenlerine ve kimliklerine yabancılaşmış olduğu gerçeğini değiştirmez. Kadınların Offred’in deyimiyle "iki bacaklı rahimlerden" ibaret sayıldığı bir düzende erkekler de "tohum zarfı" olarak rejimin geleceğine yapılan bir tür yatırım konumundadırlar. Hizmetinde bulunduğu komutanın Offred ile efendi ve kölesi gibi değil de, normal insanlar gibi iletişim kurmak istediği bölümde damızlık kızın aklından şu düşünceler geçer. "Belki 
benden bir şey istiyor, biraz duygu, onun da insan olduğuna dair bir onaylama, salt bir tohum zarfindan fazla bir şey olduğuna dair" (Atwood, 1992: 298).

Gilead'da kadınlar kendi içinde sadece doğurgan ve kısır olarak değil, ayrıca kadınlar ve "gayri kadınlar" olarak ayrılmıştır. Gayri kadınlar arasında darbe öncesi doğum yapmayı istemeyen, arzu etmeyen ya da rejim için bebek taşıma dayatmasını reddeden kadınlar yer alır. "Doğurmanın bir anlamı yok, diyorlardı. Lydia Teyze'nin burun delikleri darahyor: ne ahlaksızlk. Tembel kadınlard, diyor. Sürtüktüler" (Atwood, 1992: 130). Ayrıca ucuz ve yırtılmış giysileriyle kolayca ayırt edilebilen kadınlar, fakir erkeklerin eşleri olduklarından daha alt sınıfa ait sayllırlar. "Ekonokadın deniliyor onlara. Bu kadınların ayrı ayr işlevleri yok. Her şeyi yapmak zorundalar; yapabilirlerse” (Atwood, 1992: 32).

Gilead'da makbul bir kadın ve yasalara uygun bir damızlık kız olmanın yolu sadece hamile kalmaktan geçmez. Doğumun ne şekilde gerçekleşeceğine de devlet karar verir. Kadınlara ilaç verip acıyı hissetmemeleri için bedenlerinin uyuşturulduğu, sunî doğum sancılarının arttırıldığı dönemler geride kalmış, gerekli durumlarda anestezi kullanımı bile bırakılmıştır. "Elizabeth Teyze bunun bebek için daha iyi olduğunu söylerdi, ama ayrıca: 'Zahmetini ve gebeliğini ziyadesiyle çoğaltacağım; ağr ile evlat doğuracaksın.' Öğle yemeğinde bize kahverengi ekmek ve salatah sandviçlerin yanında bunu da verirlerdi" (Atwood, 1992: 132).

Gilead'da Marx’n "herkesten yeteneğine göre, herkese ihtiyacına göre" sözü "kudretine göre her kadından, gereksinimine göre her erkeğe" (Atwood, 1992: 135) biçiminde değiştirilmiş ve doğum "hizmetini" kutsayan yeni bir slogana dönüştürülmüştür. Bu slogan bir dua gibi her yemekten sonra üç defa okunur. Damızlık kızların tertibinden sorumlu olan Lydia Teyze, "geçiş neslini" temsil ettikleri için en zor durumda olan kuşağın Offred ve arkadaşları olduğunun bilincindedir. Zira bu kadınlar "normal" bir yaşamın içinden alınıp distopik düzenin içine hapsedilmişlerdir. Dolayısıyla kadınların özgür olduğu bir dünyanın anılarında hala yeri vardır. Özgürlüğün neye benzediğini bilen bir kuşak, tutsaklığın acısını daha derinden hisseder. "Sizden sonra gelenler için daha kolay olacak. Görevlerini gönül rızasıyla kabul edeceklerdir. Söylemediği buydu: Çünkü başka anılar olmayacak. Söylediği ise şu: Çünkü sahip olamayacakları şeyleri istemeyecekler" (Atwood, 1992: 135).

Distopyaların belirleyici özelliklerinden biri, kahramanların yaşamında geçmişle şimdi arasına çekilen setin belirginliğidir. Yeni yaşamın muktedirleri, sıklıkla geçmişte yapılan hataları yeren söylemler aracılığı ile kahramanları sistemle uyumlu hale gelmeleri yönünde uyarırlar. Arendt, totalitarizmin mutlak denetimi ele geçirdiğinde, propagandaya başvurma yerine bir öğretiyi aşılama yoluna gittiğini vurgular (Arendt, 2014: 94). Bu romanda da Lydia Teyze, "gayri-kadın belgeseli" adını verdiği kimi görüntüleri damızlık kızlara izleterek izledikleri şeyden ibret almalarını salık vermektedir. Gayrikadınların zamanlarını boşa harcadıklarını, üstelik hükümetin kadınları teşvik ettiğini ve onlara para bile verdiğini söyler. (Atwood, 1992: 136). Lydia Teyze’nin kastettiği “uygunsuz" durum, kadınların çalışarak ekonomik özgürlüklerini kazandıkları bir yaşam sürdürmeleridir.

Offred'in annesi, gençliğinde Lydia Teyze'den dinlediği gayri-kadınların tipik bir örneğidir. Offred'in bir zamanlar kendisinin de giydiğini unutmaya başladığı, ekoseli gömlek ve spor ayakkabı gibi sıradan, günlük giysiler giymesi, yeni düzende annesinin bir gayri-kadın olduğunu gösteren en önemli belirtilerdir (Atwood, 1994: 137). Offred'in bir aktivist olan annesi, 1970'lerin kadın hareketinde önemli bir itiraz konusu olan gebelik ve kürtaj eylemlerine katılmıştır. Hareketin kullandığı sloganlar arasında "Seçme özgürlüğü. Her bebek istenilmiş bir bebek olsun. Bedenlerimizi geri verin. Bir kadının yerinin mutfak masası olduğuna mı inanıyorsunuz?” yer almıştır (Atwood, 1992: 138). Romanda 1970’lerin 
feminist eylemleri ile Gilead totalitarizmini betimleyen sahneler geriye dönüş tekniği ile bir araya getirilir ve Atwood'un ikinci dalga feminizmin tarihine odaklandığı eser, "bilinçsizce ve paradoksal bir biçimde" bazı feminist taleplerin karşılandığı distopik bir toplumu betimler (Tolan, 2006: 18-19). Bu çerçevede, Offred’i derinden sarsan bir tesadüf, aktivist annesinin erkekler ve doğum hakkındaki ironik sözlerinin, kati bir resmiyet dâhilinde gerçeğe dönüşmüş olmasıdır; Offred, kendini bunların yasa haline getirildiği bir düzenin içinde bulmuştur.

"O stralarda saçı griydi, elbette. Boyamazdı. Neden olduğumdan farkh görüneyim ki? derdi. Her neyse, niye ihtiyactm olsun ki, etrafimda erkek istemiyorum, on saniyede yarm bebek yapmaktan başka ne işe yararlar ki? Erkek dediğin başka kadınlar üretmek için kadının kullandiğı bir araçtır sadece" (Atwood, 1992: 139). "Anne, diye düşünüyorum. Her neredeysen. Beni duyabiliyor musun? Bir kadın uygarlhğ istiyordun. Evet, şimdi bir tane var. Senin dediğin bu değildi, ancak işte yine de var. Küçük inayetlere şükret” (Atwood, 1992: 145).

Bir komutanın hizmetine girerek ona çocuk vermeyi başaran damızlık kız, bu görevi bir kez bile yerine getirmesi durumunda, bir daha asla gayri-kadın olma tehlikesi altında kalmayacaktır. Bebeği beslemesi için birkaç ay boyunca, biyolojik anne ile bebeği ayırmazlar. Ardından da damızlık kızı başka bir yere gönderirler, çocuk sahibi olamayan başka bir ailenin yanına "ihtiyacı olan birisiyle bunu tekrarlayabilir mi diye görmek için. Ama asla Kolonilere gönderilmeyecek, asla gayri-kadın ilan edilmeyecek. Onun da ödülü bu” (Atwood, 1992: 145).

Hemen her distopik kurguda olduğu gibi “Damızlık Kızın Öyküsü”nde de gözetlenme ve göz metaforu baskıcı denetleme mekanizmalarını temsil etmektedir. Rejimin koruyucuları olan "İnanç Muhafızları", tebdil-i kıyafet dolaşan ve damızlık kızların dış dünyayla temasını engelleyen "gözler", romanda muhbirlik sistemini temsil etmek üzere yer verilen bazı denetleyicilerdir. Meraklı turistlerin etrafını sardığı sahnede Offred, sorulara sadece mutlu olduğunu söyleyerek kısa cevaplar verip yabancıları geçiştirir. Zira herkesin muhbir yani "göz" olma ihtimalinden şüphe edilmektedir. "Çevirmenin yüzüne bakmayacak kadar akullyyım. Çevirmenlerin çoğu Göz ya da öyle söyleniyor” (Atwood, 1992: 38). Bireyin etrafının muhbirlerle sarılı olduğu ya da devamlı gözetlendiği hissine kapılması ve bu durumun sürekliliğinin devlet tarafından bilinçli olarak sağlanması, distopyalarda sık karşılaşılan eleştirel odaklardan biridir. Lydia Teyze'nin sözleriyle "Tanrı’nın Gözleri yeryüzünün her köşesine uzanır" (Atwood, 1992: 221) fikri bir devletin vatandaşları üzerinde tam denetim kurmak, üstelik fiilen denetlenemediği durumlarda dahi onu kendi eylemleri üzerinde otokontrole itmek için başvurduğu en bilinen yöntemlerdendir.

Ekiz, distopik tasarımın mühim bir özelliğinin "bir milat fikri veya 'tarih-öncesi' inşa etmek” olduğunu belirtir (Ekiz, 2018: 25). Romanda darbe bir milat kabul edilirken, Gilead öncesi yaşamın tüm sosyal kurumları ve değerleri de dönüşüme uğramış hatta ortadan kaldırılmıştır. Yeni dünyada adaletin sağlanmasından sorumlu avukatlar yoktur, zira Gilead rejimi adaleti en doğru ölçekte tesis ettiği iddiasındadır ve kendi varlığı üzerinde hiçbir güç tanımamaktadır. Ayrıca öğretim faaliyetleri de gereksiz sayıldı̆̆ı için sona erdirilmiştir, kadınların okuması ve yazması ise yasaklanmıştır. "Gilead Cumhuriyeti, derdi Lydia Teyze, sinır tanımaz. Gilead içinizdedir. Eskiden burada doktorlar otururdu, avukatlar, üniversite profesörleri. Artik avukatlar yok ve üniversite de kapal”"(Atwood, 1992: 32).

Offred, gündelik yaşamın içinde akıp giderken ne kadar kıymetli özgürlük göstergeleri olduğunun farkına varamadığı bir dizi eylemi özlemle anımsamaktadır. “...kendi paramı, kendi başıma kazandı̆̆ım parayı. Böyle bir denetime sahip olmayı düşünüyorum” (Atwood, 1992: 33). Bir kadının kendi ayakları üzerinde durması, çalışıp para kazanması, kişisel eşyalara sahip olması artık imkânsız bir hayal gibi 
görünmektedir. "Bütün o kadınların iş sahibi olmaları: şimdi inanması zor, ancak binlercesinin işi vardı o zamanlar, milyonlarcasının. Normal bir şey gözüyle bakılırdı buna” (Atwood, 1992: 199).

Yeni düzen kurucuların eski yaşamı nasıl yorumladıkları göz önünde bulundurulduğunda, distopik söylemle günümüz söylemi arasında bir takım doğrusallıklar dikkat çekmektedir. Günümüzde kadınların sosyal yaşamın dışına itilmesine ve ekonomik sahada söz sahibi olmak yerine sadece ev içi emekçiler olarak konumlandırılmasına hizmet eden söylemlerin dayandırıldığı, kadın ve erkeğin "doğasına" ilişkin düşüncelerin tahrifine dayanan argümanların benzerleri romanda da yer almaktadır. Sözgelimi komutanlardan biri, eski ve yeni düzenin miladi dönüşüm noktasını, doğa yasaları üzerinden şöyle izah etmektedir. "Tarihsel bağlamda konuşursak, o yıllar tam bir anomaliydi, dedi Komutan. Kazara yaşandılar sadece; bizim bütün yaptı̆̆ımız, her şeyi Doğa'nın normlarnna uydurmak" (Atwood, 1992: 251). Kadınların farklı bir doğaya sahip olması konusunda feministlerin itiraz etmesini gerektiren bir nokta bulunmadığını vurgulayan Holmstorm, asıl meselenin "kadınların doğasının bu bağlamda kadınların nasıl yaşaması ya da yaşamaması gerektiği konusunda hiçbir ahlaki belirleme taşımadığı” olduğunu belirtir (Holmstorm, 2012: 277). Kadınların dişi cinsin tipik bir üyesi olarak tanımlandığını ve erkeklerden gebe kalabilme ve doğum yapabilme özelliği ile ayrıldıklarını; yani kadınların "doğasını" kabul eden Holmstorm (2012: 266) kadın ve erkeklerin biyolojik değil, toplumsal gruplar olarak farklılıklarının söz konusu edildiği bir zeminde hak arayışlarının sürdürüldüğünü vurgular. Holmstorm’un bu açık ve anlaşılır itirazı, kadının “doğasını” temel almaya eğilimli olan; oysa bu yolla onları özel alana hapsederek kamusal alanı yeniden tekeline almaktan başka gayesi bulunmayan -gerek güncel, gerekse tezahürlerini distopyalarda bulabildiğimiz- söylemlere güçlü bir yanıt niteliğindedir.

Lydia Teyze'nin söylevlerinden bıkmış olmasına karşın, Offred kendi algılarında meydana gelen değişimi şaşkınlık içinde fark eder. Zamanla yeni sistem kendisini de ele geçirmeye başlamıştır. Eylemlerin rutinliği ve yıllar geçtikçe "geçmiş yaşamdan" ve eski normlardan kopması, onu yeni sisteme alıştırmıştır. Öyle ki yolda “Gleninki” ile yürürken karşılaştıkları üniformasız kadınlar gözüne çıplak gibi görünmeye başlamıştır bile. "Onun da gözlerini bu kadınlardan ayıramadığını biliyorum. Büyülendik, ancak tiksindik de. Çıplak gibiler. Çok kısa sürmüş, fikrimizi değiştirmemiz, bu tür şeyler hakkında. Sonra düşünüyorum: Eskiden ben de böyle giyinirdim. Özgürlüktü bu” (Atwood, 1992: 37). Zaman geçtikçe özgürlük fikri Gilead sakinlerine korkutucu gelmeye başlamıştır. Dışarısı bilinmeyen bir dünyaya, içerisi ise geçen zamanla beraber "olağanın" yeniden anlamlandırıldığı akışa dâhil olmuştur. “Özgürlük tadın kaybetmeye, bu duvarları güvenli bulmaya başlamıştık bile” (Atwood, 1992: 153). Rejimin Lydia Teyze'nin sözlerinde karşıllğını bulan politikası, yeni düzeni Gilead sakinlerine kanıksatarak, neyin normal olduğuna ilişkin algının zemin değiştirmesi üzerine kuruludur. "Alıştığınız şey, derdi Lydia Teyze, stradanllktır. Bu size şimdi stradan görünmeyebilir, ancak bir süre sonra stradan görünecektir. Stradan olacaktr" (Atwood, 1992: 43).

Ömrü bu distopik düzende günden güne harcanıp giden Offred, sistem içinde suçluların varlı̆̆ını bir umut işareti olarak yorumlar. Hapsedildiği dünyanın dışında bir direniş sürdürüldüğü ihtimalini dikkate alır. "Gölgesiz ışığın olamayacă̆ına inandığım gibi inanıyorum direnişe; ya da daha doğrusu, ışık olmazsa gölge olmayacă̆ına inandığım gibi. Bir direniş olmalı, yoksa televizyonda gösterilen bütün o suçlular nereden geliyorlar?” (Atwood, 1992: 122). Romanın sonunda, Offred'in Gilead'dan kurtulmayı başarıp başaramadığı belirsiz bırakılır. "Ve böylece tırmanıyorum, içerideki karanlı̆ a; aydınlı̆̆a ya da" (Atwood, 1992: 334). Romanın ekindeki "tarihsel notlar" bölümünde, Offred'in önsezileri doğrultusunda, Gilead Cumhuriyeti’nin çoktan yıkıldı̆̆ı ve artık sadece bir araştırma konusuna dönüştüğü dönemde düzenlenen bilimsel toplantıya yer verilir. Toplantıda, Gilead'dan kaçan 
kadınlardan birinin yaşadıklarını anlattığı bant kayıtları sayesinde haberdar olunan bu sistem, bütün yönleriyle tartışılmaktadır.

Romanın finalinde, gözetleme mekanizmalarının tüm yaygınlığına karşın, kadının söz söyleme ve yazma gücünün engellenemediği göz önünde bulundurulursa, "Damızlık Kızın Öyküsü”, doğarlık kavramının taşıdığı kırılganlığın distopik senaryosunu içermekle beraber, umut ve mucize formundaki yansımasını da göz ardı etmemiştir. Arendt'in "hepimiz dünyaya doğum sayesinde, yeni gelenler ve başlangıçlar olarak geldik" (Arendt, 1997: 91) görüşü uyarınca, Offred adını almadan önceki kimliğiyle June karakterinin kendi doğarlığı, aynı anda direniş ve umudu temsil eder -ki baskının olduğu yerde mutlaka direniş de vardır. 4

\section{Sonuç}

Modern devletin gözetleme teknikleri, distopyaları gerçekliğimize uzak kurgusal evrenler olmaktan çıarıp, gündelik yaşamımızı distopik edebi yapıtların anlatı konusu edindiği tehlikeli sulara çekmeye başlamıştır. Felaket tasavvurları ile içinde devindiğimiz yaşantının sınırları birbirine karışmaya başladığında, distopyaların uyarı niteliğindeki olay örgüsünün bugünle benzeşmesi daha dikkat çekici hale gelmektedir. Bu bağlamda “Damızlık Kızın Öyküsü”nün, çeşitli ülkelerde gerçekleştirilen baskıcı üreme politikalarına yönelik gösterilerde, aktivistlerin sloganlarını üzerine inşa ettikleri bir temaya dönüştüğü görülmektedir. Özellikle Trump karşıtı eylemlerde kadın göstericilerin, kırmızı pelerinli giysiler ve beyaz başlıklardan oluşan tipik damızlık kız kostümleri ile sokakları doldurarak slogan atmaları basına yansımıştır.

Arendt’in baskıcı güç odaklarının karşısına olumlu bir kavramsallaştırma olarak yerleştirdiği "doğarlık" anlayışı, yeniden başlamayı ve çoğulluk dolayımıyla özgürleşmeyi temsil etmesi bakımından kısıtlayıcı, tektipleştirici, ayrıştırıcı beden politikalarının hüküm sürdüğü düşünsel ve eylemsel alanlarda yapıcı bir biyopolitika anlayışı olarak öne çıkmaktadır. Ancak doğarlık kavrayışının Orta Çağ düşünürlerinin söylemlerinden ilham alan temelleri, bu kavramı doğum eylemini öteleyen bir başlangıç metaforu olarak ele almayı feminist perspektif uyarınca imkânsız hale getirmektedir. Devletin tasarrufuna geçen doğum eylemi, canlının yaşatılmasını ve yeteneklerinden faydalanılmasını savunan beden politikalarının elinde işlevsel bir oyuncağa çevrilmiş olur. Siyasal iktidarın denetimindeki doğarlık, distopik kurguların bir izdüşümüne dönüssen modern gerçeklikte, namlunun ucuna muktedirin baskısını değil, tabi olanın çaresizliğini yerleştirmiştir. Savaş cephesinde ve toplama kamplarında yaşanan kadına yönelik şiddetin bir türü olarak toplu tecavüzler, doğarlığın olumlu bir başlangıcı temsil etmek yerine; sistematik zulüm, asimilasyon ve soykırım amaçlarına da hizmet edebileceğini örneklemektedir. Margaret Atwood'un "Damızlık Kızın Öyküsü” adlı distopyası ise, sözünü ettiğimiz olumsuz tezahürlerin kurgusal bir görünümünü sunar ve ekolojik nedenlerle kısırlığın yaygınlaştı̆̆ bir dönemde, darbeyle iktidara gelen bir grubun doğurgan kadınları kendi rejimleri lehine mülk hale getirmelerinin ve onları sistematik tecavüz yoluyla birer doğum makinesi olarak çalıştırmalarının hikâyesini anlatır. Öykülenen püriten düzende, Arendt’in de başvurduğu Orta Çağ düşünürlerine ait olan, doğumun mucizevi niteliğine ilişkin söylemlere başvurulmaktadır.

Feminizmin ikinci dalgası içinde yer alarak kadının doğasına ve annelik potansiyeline yaslanan yaklaşımlara ve bu hareketten bağımsız bir düşünür olarak Arendt’in doğarlık anlayışına yönelik eleştirel metinlerde, her devirde devletin tasarruf yetkisi altında bulunan doğumun, gerek bir kavram ya

"Bu demektir ki, iktidar ilişkilerinde mutlaka direnişs imkânı vardır, zira hiç direniş imkânı (şiddetli direniş gösterme, kaçıp kurtulma, hileye başvurma, durumu tam tersine çeviren stratejiler) olmasaydı iktidar ilişkisi de olmazdl” (Foucault, 2014: 236). 
da siyasal metafor; gerekse fiili bir süreç olarak sadece pozitif eylem potansiyeline sahip olmadığ 1 ifade edilmektedir. Doğarlık, özgürlükçü ya da baskıcı rejimler marifetiyle iki farklı anlam dünyası tarafından kuşatılabilmektedir. Ancak "Damızlık Kızın Öyküsü”nde örneklendiği biçimiyle bedensel denetim altında ve cinsel şiddet yoluyla gerçekleştirilen zorunlu doğumların kısıtlayıcı karakterini göz ardı etmemekle beraber, Arendt’in ortaya koyduğu biçimiyle doğarlığın özgürleştirici kavramsal gücüne sahip çıkmak, tarihsel ilerlemenin yapıcı bir koşulu olarak karşımızda durmaktadır.

\section{Kaynakça}

Arendt, H. (1994). İnsanlık Durumu. (Çev. B.S. Şenel). İstanbul: İletişim.

Arendt, H. (1997). Şiddet Üzerine. (Çev. B. Peker). İstanbul: İletişim.

Arendt, H. (2014). Totalitarizmin Kaynakları 3. Totalitarizm. (Çev. İ. Serin). İstanbul: İletişim.

Argunşah, H. (2016). Kadın ve Edebiyat. Kendini Yazmak. İstanbul: Kesit.

Atwood, M. (1992). Damızlık Kızın Öyküsü. (Çev. S. \& Ö. Kabakçıŏlu). Afa: İstanbul.

Atwood, M. (2004). The Handmaid's Tale and Oryx and Crake "In Context". Publications of the Modern Language Association of America, 119 (3), 513-517.

Benhabib, S. (1993). Feminist Theory and Hannah Arendt's Concept of Public Space. History of the Human Sciences, 6 (2), 97-114.

Benhabib, S. (1995). The Pariah and Her Shadow: Hannah Arendt's Biography of Rahel Varnhagen. Political Theory, 23 (1), 5-24.

Benhabib, S. (2003). The Reluctant Modernism of Hannah Arendt. Lanham, Boulder, New York, Toronto, Oxford: Rowman \& Littlefield Publishers.

Berktay, F. (2010). Felsefenin Kadına Bakışı. (Der. H. Durudoğan vd.) Türkiye'de Toplumsal Cinsiyet Çalışmaları içinde (ss.23-34). İstanbul: Boğaziçi Üniversitesi Yayınları.

Cavarero, A. (1995). In Spite of Plato: Feminist Rewriting of Ancient Philosophy. (Trans. S. AnderliniD’Onofrio \& A. O’Healy). New York: Routledge.

Cavarero, A. (2014). "A Child Has Been Born unto Us": Arendt on Birth (Trans. Silvia Guslandi, Cosette Bruhns). philoSOPHIA, 4 (1), 12-30.

Collin, F. \& Laborie, F. (2009). Annelik. (Ed. H. Hirata vd.). Eleştirel Feminizm Sözlüğü içinde (38-45. ss.). (Çev. G. Acar-Savran). Kanat: İstanbul.

Coontz, S. (2012). Marx ve Engels’i Aile Hakkında Yeniden Değerlendirmek. (Ed. Nancy Holmstorm). Sosyalist Feminist Proje: Teori ve Politikanın Günümüz Okuması Cilt 1. içinde (ss. 229-234). (Çev. Ö. Kelekçi). Kalkedon: İstanbul.

Coşkun, B. (2013). Kadınlık Durumu ile İlişkisinde Hannah Arendt. Posseible Düşünme Dergisi, 2 (4), 1-14.

Disch, L. J. (1995). "On Friendship in 'Dark Times" in (Ed. Bonnie Honig), Feminist Interpretations of Hannah Arendt (pp. 285-312). University Park: Penn State University Press,

Ekiz, C. (2018). Distopik Devletin Biyopolitikası. Bitlis Eren Üniversitesi Sosyal Bilimler Enstitüsü Dergisi, 7 (1), 13-31.

Engels, F. (2003). Ailenin, Özel Mülkiyetin ve Devletin Kökeni. (Çev. K. Somer). Yyy.: Eriş.

Ferguson, A. (2012). Annelik ve Cinselliği Tahayyül Etmek: Feminist-Materyalist Bir Yaklaşım. (Ed. Nancy Holmstorm). Sosyalist Feminist Proje: Teori ve Politikanın Günümüz Okuması Cilt 1. içinde (ss. 235-250). (Çev. Ö. Kelekçi). Kalkedon: İstanbul.

Foucault, M. (2007). Cinselliğin Tarihi (Çev. H.U. Tanrı̈ver). İstanbul: Ayrıntı.

Foucault, M. (2014). Özne ve İktidar. (Çev. I. Ergüden \& O. Akınhay). İstanbul: Ayrıntı. 
Gunneflo, M. (2015). Rudolf Kjellén: Nordic Biopolitics Before the Welfare State. Retfærd: Nordisk juridisk tidsskrift, 35(3), 28-39.

Holmstorm, N. (2012). Kadınların Doğasının Marksist Teorisi. (Ed. Nancy Holmstorm). Sosyalist Feminist Proje: Teori ve Politikanın Günümüz Okuması Cilt 2. içinde (ss. 261-290). (Çev. Ö. Kelekçi). Kalkedon: İstanbul.

Kartal, O. (2018). Biyopolitik Distopya: Yorgos Lanthimos Sinemasından “İnsan” Manzaraları. Cogito, $5,101-119$.

Kartal, O. (2018). Hannah Arendt’in Doğarlık Kavrayışı ve Siyaset Felsefesi İçin Yeni Bir Hareket Alanı. flsf Felsefe ve Sosyal Bilimler Dergisi, 12, 199-216.

Lemke, T. (2016). Biyopolitika. (Çev. U. Özmakas). İstanbul: İletişim.

Lhomond, B. (2009). Cinsellik. (Ed. H. Hirata vd.). Eleştirel Feminizm Sözlüğü içinde (ss.64-69). (Çev. G. Acar-Savran). Kanat: İstanbul.

Markus, M. (1987). The “Anti-Feminism” of Hannah Arendt. Thesis Eleven, 17(1), 76-87.

Schott R. M. (2010). Natality and Destruction: Arendtian Reflections on War Rape in (Ed. R. M. Schott), Birth, Death, and Femininity: Philosophies of Embodiment, (pp. 49-69). Bloomington and Indianapolis: Indiana University Press.

Schott, R. M. (2011). War Rape, Natality and Genocide. Journal of Genocide Research, 13(1-2), 5-21.

Söderbäck, F. (2018), Natality or Birth? Arendt and Cavarero on the Human Condition of Being Born. Hypatia, 33: 273-288.

Tolan, F. (2005). Feminist Utopias and Questions of Liberty: Margaret Atwood's The Handmaid's Tale as Critique of Second Wave Feminism. Women: A Cultural Review, 16: 1, 18-32.

Totschnig, W. (2017). Arendt's Notion of Natality. An Attempt at Clarification. Ideas y Valores, 66 (165), 327-346.

Trimble, S. (2011). Maternal Backgrounds in Children of Men Notes Toward an Arendtian Biopolitics. Science Fiction Film and Television, 4 (2), 249-270.

Willard, M. (2013). Birth as Labor and Natality: Hannah Arendt and the Politics of Maternality. Theology \& Sexuality, 19 (3), 227-245. 